\title{
Projected Costs of a Grid-Connected Domestic PV System Under Different Scenarios in Ireland, Using Measured Data from a Trial Installation
}

\author{
Lacour Ayompe \\ Technological University Dublin, lacour.ayompe@tudublin.ie \\ Aidan Duffy \\ Technological University Dublin, aidan.duffy@tudublin.ie \\ Sarah McCormack \\ University of Dublin, Trinity College, sarah.mccormack@tcd.ie
}

See next page for additional authors

Follow this and additional works at: https://arrow.tudublin.ie/dubenart

Part of the Power and Energy Commons, and the Urban, Community and Regional Planning Commons

\section{Recommended Citation}

Ayompe, L., Duffy, A., McCormack, S., \& Conlon, M. (2010). Projected costs of a grid-connected domestic PV system under different scenarios in Ireland, using measured data from a trial installation. Energy Policy, vol. 38, pp. 3731-3743. doi:10.1016/j.enpol.2010.02.051

This Article is brought to you for free and open access by the Dublin Energy Lab at ARROW@TU Dublin. It has been accepted for inclusion in Articles by an authorized administrator of ARROW@TU Dublin. For more information, please contact arrow.admin@tudublin.ie, aisling.coyne@tudublin.ie,gerard.connolly@tudublin.ie. Funder: Department of Education, TSR Strand III

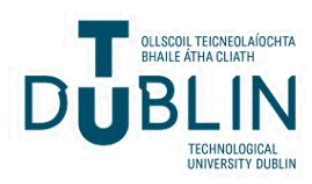




\section{Authors}

Lacour Ayompe, Aidan Duffy, Sarah McCormack, and Michael Conlon

This article is available at ARROW@TU Dublin: https://arrow.tudublin.ie/dubenart/4 


\title{
Projected costs of a grid-connected domestic PV system under different scenarios in Ireland, using measured data from a trial installation
}

\author{
L.M. Ayompe ${ }^{\text {a,* }}$, A. Duffy ${ }^{a}$, S.J. McCormack ${ }^{\text {b }}$, M. Conlon ${ }^{c}$ \\ ${ }^{a}$ Department of Civil and Structural Engineering, School of Civil and Building Services, Dublin Institute of Technology, Bolton Street, Dublin 1, Ireland \\ ${ }^{\mathrm{b}}$ Department of Civil, Structural and Environmental Engineering, Trinity College, Dublin 8, Ireland \\ ' School of Electrical Engineering Systems, Dublin Institute of Technology, Kevin St, Dublin 8, Jreland,
}

\section{A R T I C L E I N F O}

Article history:

Received 14 August 2009

Accepted 24 February 2010

\section{Keywords:}

PV system

Net present value (NPV)

Electricity cost

Grid parity

31 Q2 Life cycle cost

\section{Introduction} Government, 2009).

\begin{abstract}
A B S T R A C T
This paper presents results of a study of projected costs for a grid-connected PV system for domestic application in Ireland. The study is based on results from a $1.72 \mathrm{kWp}$ PV system installed on a flat rooftop in Dublin, Ireland. During its first year of operation a total of $885.1 \mathrm{kWh} / \mathrm{kWp}$ of electricity was generated with a performance ratio of $81.5 \%$. The scenarios employed in this study consider: a range of capital costs; cost dynamics based on a PV module learning rate of $20 \pm 5 \%$; projections for global annual installed PV capacity under an advanced and moderate market growth conditions; domestic electricity cost growth of $4.5 \%$ based on historic data; and a reduction of $25 \%$ or $50 \%$ in the $\mathrm{CO}_{2}$ intensity of national electricity production by 2055 . These scenarios are used to predict when system life cycle production costs fall to grid prices (grid parity).

Average NPV and electricity generation costs ranged from $-€ 14,330$ and $0.58 € / \mathrm{kWh}$ and were close to zero and $0.18 € / \mathrm{kWh}$ for a system installed in 2009 and 2030, respectively. However, under optimistic conditions NPVs are positive for systems installed after 2021 and grid parity occurs in 2016. Findings are compared with similar international studies.
\end{abstract}

(c) 2010 Published by Elsevier Ltd.

In April 2008, the Irish Government indicated its interest in micro-generation by announcing the implementation of a micro- and small-scale electricity generation programme. Pilot trials were due to be installed in 2009 for domestic scale PV systems (Sustainable Energy Ireland, 2008b). Furthermore, in February 2009 the Irish Government and the largest Irish electricity supplier, the Electricity Supply Board (ESB) introduced a feed-in tariff of $19 €$ cents per kWh for electricity from micro-generation (Department of Environment Heritage and Local

In order to evaluate the performance of PV systems in Ireland it is imperative that both field trials which provide information on the annual energy yield of typical installations as well as studies to determine the economics and environmental benefits of PV systems be undertaken. This information is necessary for evidence-based policy design and implementation.

During operation, PV systems generate electricity without the emission of greenhouse gases such as $\mathrm{CO}_{2}$, while displacing

\footnotetext{
* Corresponding author. Tel.: +35314023940.

E-mail addresses: lacour.ayompe@dit.ie (L.M. Ayompe), aidan.duffy@dit.ie (A. Duffy).
}

electricity generated from conventional power plants. The adoption of PV systems offers significant benefits to household in terms of reduced energy bills and to society as a whole in terms of reduced greenhouse gas emissions (Ren et al., 2009). Numerous issues remain still to be resolved if PV micro-generation is to be implemented on a large-scale within the residential sector. Some of these issues include: high electricity generation costs; high capital cost, high $\mathrm{CO}_{2}$ abatement costs; lack of an adequate tariff structure for electricity sale; grid integration; and load profile mismatch with electricity generation.

The main objective of this paper is to provide an insight into the projected energy, economic and environmental performance of PV systems for domestic applications in Ireland based on system cost, system performance, solar radiation data, $\mathrm{CO}_{2}$ emission and energy output dynamics. This would provide useful information to potential investors and policy makers.

\section{Methodology}

Performance results of a $1.72 \mathrm{kWp}$ PV system installed in Dublin, Ireland were used to determine the annual performance ratio and total in-plane solar insolation which are important parameters used to determine annual energy generation. The total energy generated throughout the PV system's life of 25 years was 
Table 1

Economic parameters.

\begin{tabular}{|c|c|c|c|}
\hline Description & Unit & Symbol & Value \\
\hline Module price & $€ 2009 / \mathrm{kW}_{\mathrm{p}}$ & $C_{m}$ & $5700 \pm 1100$ \\
\hline BOS cost factor & $\%$ & $k_{\text {bos }}$ & 54 \\
\hline BOS replacement cost factor & $\%$ & $k_{\text {bosplp }}$ & 70 \\
\hline BOS component life time & Year & $N_{r}$ & 10 \\
\hline Interest rate & $\%$ & $i$ & 5 \\
\hline Discount rate & $\%$ & $d$ & 5 \\
\hline Variable cost factor & $\%$ & $k_{v}$ & 1 \\
\hline Peak power & kWp & $P_{\text {peak }}$ & 1.72 \\
\hline Global radiation & $\mathrm{kWh} / \mathrm{m}^{2} \mathrm{yr}$ & $G_{m}$ & 1035 \\
\hline Standard radiation & $\mathrm{kW} / \mathrm{m}^{2}$ & $I_{\text {stc }}$ & 1 \\
\hline Annual degradation of energy yield & $\%$ & ssc & $0.82 \%$ \\
\hline Performance ratio & $\%$ & Q & 80.8 \\
\hline Base year electricity export price (feed-in tariff) & $€ 2009 / \mathrm{kWh}$ & $P_{\text {elex }}$ & 0.19 \\
\hline Base year grid supplied electricity price & $€ 2009 / \mathrm{kWh}$ & $P_{\text {elim }}$ & 0.16 \\
\hline Annual growth rate of grid supplied electricity price & $\%$ & $r_{\text {inm }}$ & 4.5 \\
\hline Annual growth rate of feed-in tariff & $\%(€ 2009)$ & $r_{\mathrm{ex}}$ & 0 \\
\hline PV system life time & Years & $N$ & 25 \\
\hline Percentage of on-site electricity use & $\%$ & $E_{\text {on }}$ & 96 \\
\hline
\end{tabular}

estimated taking into consideration an annual output drop as a result of module degradation as a result of exposure to ultraviolet radiation. A PV system life of 25 years was chosen in this study since it is same as the performance warranty period of many module producers (EPIA, 2008).

The average installed cost of PV systems in Ireland in 2009, a learning rate of $20 \pm 5 \%$ and two scenarios for PV system annual installed capacity growth were used to project the system's installed cost until 2030. These projected costs together with the economic parameters in Table 1 were used to calculate projected net present value and the life cycle cost of electricity generation for different years of installation at which the PV system is installed.

Net life cycle greenhouse gas (GHG) emissions were calculated taking into consideration two scenarios reflecting different trends in the GHG intensity of electricity production in Ireland. The net life cycle GHG emissions were used to evaluate GHG abatement costs associated with PV generated electricity in different years of installation.

Key assumptions:

- The current feed-in tariff is applicable throughout the PV system's life.

- $\mathrm{CO}_{2}$ emissions due to embodied energy can be ignored from a national emissions policy perspective since PV modules and system components are not manufactured in Ireland.

- The inverter is replaced after 10 years.

installed at the rooftop of the Focas Institute building Dublin Institute of Technology, Ireland. It consisted of 8 modules covering a total area of $10 \mathrm{~m}^{2}$ with an installed capacity of $1.72 \mathrm{~kW}_{\mathrm{p}}$. The Sanyo HIP-215NHE5 modules were each of $215 \mathrm{~W}_{\mathrm{p}}$ capacity and comprised 72 solar cells made of thin mono-crystalline silicon wafer surrounded by ultra-thin amorphous silicon layers. The modules had an efficiency of $17.2 \%$ under standard test conditions and were connected in series. The to the latitude of Dublin, facing south at an azimuth angle of zero degrees. The PV modules were not cleaned throughout the monitoring period. A single phase Sunny Boy SB 1700 inverter was used to convert DC to AC which was fed directly into the building. The inverter had a maximum efficiency of $93.5 \%$ and maximum AC power of $1700 \mathrm{~W}$. In-plane total solar radiation was measured using a Sunny SensorBox. Additional sensors for measuring ambient temperature, wind speed and temperature at the back of one of the PV modules were connected to the SensorBox. The solar radiation sensor had an accuracy of $\pm 8 \%$ and a resolution of $1 \mathrm{~W} / \mathrm{m}^{2}$. The PV module temperature sensor was a PT 100-M type with accuracy of $\pm 0.5{ }^{\circ} \mathrm{C}$ while the ambient temperature sensor was a JUMO PT $100 \mathrm{U}$ type with accuracy of $\pm 0.5{ }^{\circ} \mathrm{C}$. The anemometer was a Thies small wind transmitter with accuracy of $\pm 5 \%$. Fig. 1 shows the PV modules and inverter installation.

\subsection{Solar radiation and performance ratio}

The PV system was monitored between November 2008 and October 2009. Fig. 2 shows variation of monthly average daily total in-plane long-term solar insolation for Dublin, performance ratio and total in-plane solar insolation over the monitored period. A horizontal surface in Dublin receives on average 920 peak sunshine hours annually. Long-term monthly average daily total in-plane $\left(53^{\circ}\right)$ solar insolation values were obtained using RetScreen4 software (RETScreen International, 2009). The PV system's annual performance ratio was $81.5 \%$ while the annual total in-plane solar insolation over the monitored period and the long-term annual average for Dublin were 1043 and $1034 \mathrm{kWh} /$ $\mathrm{m}^{2}$, respectively. The annual total in-plane solar insolation over the monitored period was $0.83 \%$ higher than the long-term average so the corrected long-term performance ratio of $80.8 \%$ was used in this study.

\subsection{PV system cost}

The installed cost of a roof mounted, grid-connected PV system depends on its capacity; type of PV modules; nature of the building on which it is to be installed; cost of balance of system (BOS) components and installation cost. A survey of 16 crystalline PV systems installed under the government pilot trial programme administered by Sustainable Energy Ireland in 2009 with capacities between 1-6 kW was conducted. Results showed that unshaded modules were fixed, inclined at an angle of $53^{\circ}$ equal 

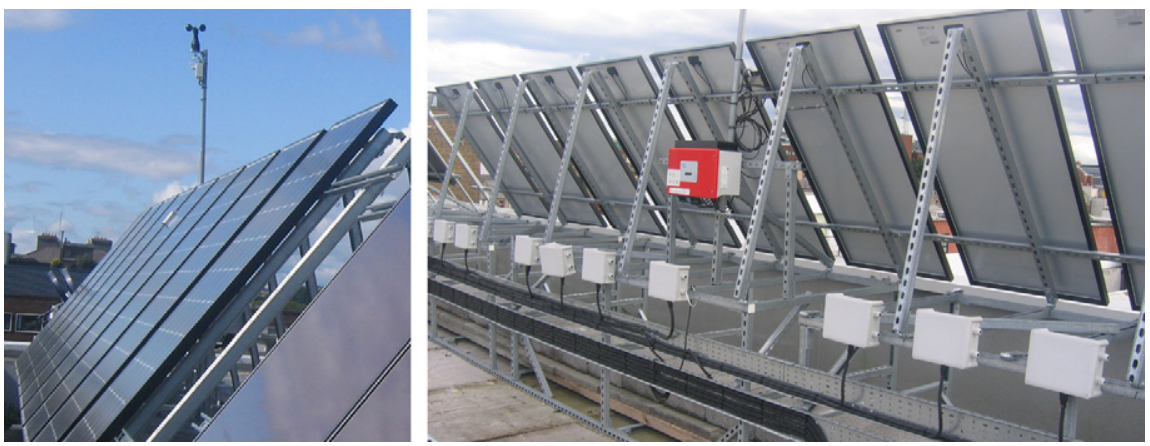

Fig. 1. PV modules and inverter installation.

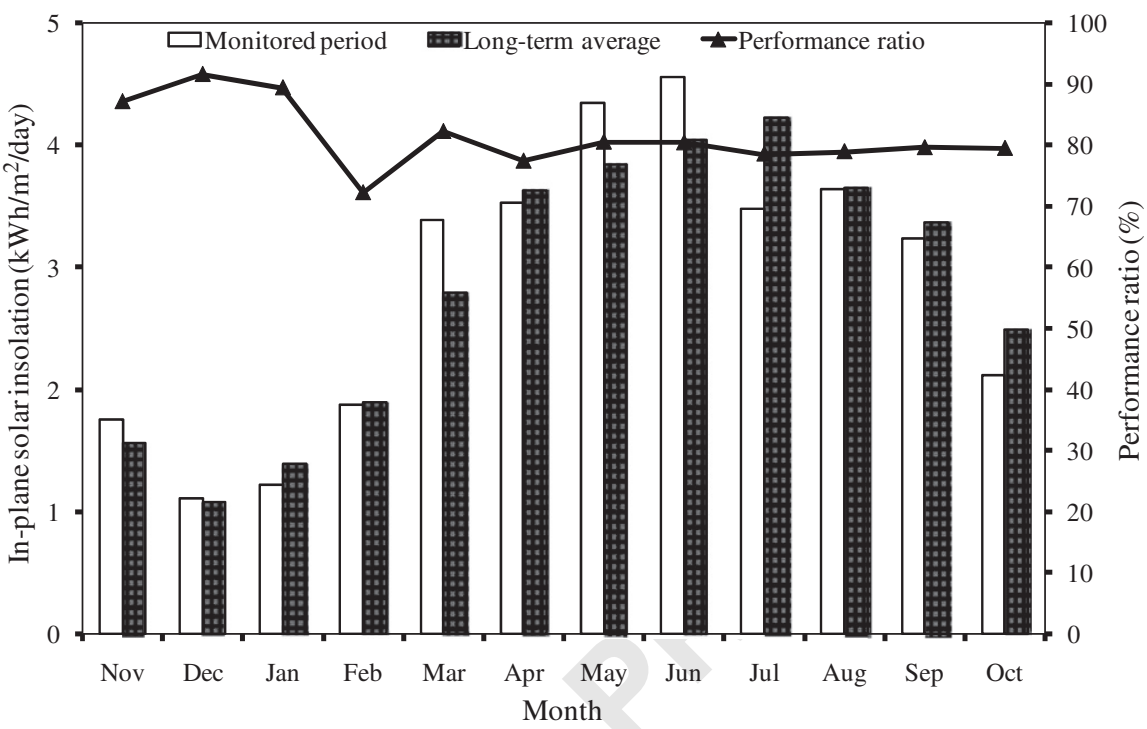

Fig. 2. Monthly average daily performance ratio, total in-plane solar insolation over the monitored period and long-term total in-plane solar insolation for Dublin.

the average installed PV system cost including value added tax was $8750 \pm 1700 € / \mathrm{kW}_{\mathrm{p}}$ with BOS accounting for $30-40 \%$. In this study $35 \%$ was chosen as the average BOS cost factor of the PV system. The average PV module cost was $5700 \pm 1100 € / \mathrm{kW}_{\mathrm{p}}$ with BOS accounting for $54 \%$ of this cost. An economic analysis was conducted using three PV module costs notably 4600,5700 and $6800 € / \mathrm{kW}_{\mathrm{p}}$. BOS of a PV system consists of all the systems or engineering components apart from the PV modules or cells. It primarily consists of an inverter to transform the direct current (DC) output from the PV array into a form of alternating current (AC) electricity that can be synchronized with and connected to the electric utility grid. It also involves support structures and all the cost of labour involved in system installation (Shum and Watanabe, 2008).

Despite an impressive growth in annual PV installation in Europe, Ireland still lags with virtually little or no installations. In 2008, the cumulative installed PV capacity in Ireland was $0.4 \mathrm{MW}_{\mathrm{p}}$ made up of 0.1 and $0.3 \mathrm{MW}_{\mathrm{p}}$ of grid-connected and off-grid capacity, respectively. The installed photovoltaic power per inhabitant in Ireland was $0.09 \mathrm{~W}_{\mathrm{p}}$ /inhabitant while the EU 27 average was $19.2 \mathrm{~W}_{\mathrm{p}}$ /inhabitant (Eurobserv'er, 2009). The small PV market size in Ireland indicates why PV system prices are relatively higher than those in other countries with more established markets such as Germany, Spain and Italy.

In order to take into account cost dynamics of the PV system, experience curve analysis was used. The concept of learning-by- doing expresses that accumulating the deployment or use of a technology increases the corresponding experience, which typically results in the optimization of the process involved. In particular, technology improvements are often economic in nature and thus result in cost reductions, so that changes in cost or price are usually used as a proxy for learning-by-doing Ferioli et al. (2009). Learning curves are usually expressed as (van der Zwaan and Rabl, 2003; Bhandari and Stadler, 2009; Ferioli et al., 2009)

$$
C\left(x_{t}\right)=C\left(x_{0}\right)\left(x_{t} / x_{0}\right)^{b}
$$

where $x_{t}$ is the cumulative installed PV module capacity at year $t$; $b$ the learning parameter or learning elasticity parameter or rate of innovation; $C\left(x_{t}\right)$ the PV module cost per $\mathrm{kW}_{\mathrm{p}}$ at year $t ; C\left(x_{0}\right)$ the PV module cost at an arbitrary starting year; $x_{0}$ the cumulative installed PV module capacity at an arbitrary starting point.

Learning curves are derived by fitting Eq. (1) to cost and production data observed in the past. The starting point then ideally corresponds to the first unit of production. In practice, however, it often proves more appropriate to choose a later (but still early) stage of deployment for $t=0$, and for the purpose of estimating future cost reductions on the basis of learning curves, it can be convenient to use the present cumulative production as starting point Ferioli et al. (2009).

The learning rate (LR) is defined as the relative cost reduction (in \%) after each doubling of cumulative production, and is given 
as Ferioli et al. (2009)

$\mathrm{LR}=1-2^{b}$

With every doubling of cumulative production, costs decrease to a value expressed as the initial cost multiplied by a factor called the progress ratio. The progress ratio (PR) is given as (van der Zwaan and Rabl, 2003; Bhandari and Stadler, 2009)

$\mathrm{PR}=1-\mathrm{LR}=2^{b}=2^{\ln \frac{\mathrm{C}\left(x_{t}\right)}{C\left(x_{0}\right)} / \ln \frac{Q_{t}}{Q_{0}}}$

Learning at PV module level makes no distinction between global and local learning, since most of the module manufacturing is done by internationally operating companies and there is extensive exchange of scientific and technological information on module technology (Bhandari and Stadler, 2009). Shum and Watanabe (2008) argue that BOS learning is mostly local in nature while module learning is relatively global. Therefore, BOS learning can mostly be attributed to cumulative experience of system design, integration and installation attained through greater system integration and a reduction in the number of BOS parts.

A learning rate of $20 \%$ with a sensitivity range of $\pm 5 \%$ that accounts for uncertainties of PV technologies and cost development as recommended by Neij (2008) was used in this study. Future PV module costs were evaluated using learning rates of $15 \%$ and $25 \%$ (progress ratio of 0.85 and 0.75 , respectively). In order to extrapolate future costs of PV modules, it is important to estimate future global installation of PV systems.

Global PV electricity generating technology has sustained an impressive annual growth rate compared with other renewable energy generating technologies. Total global installed capacity of grid-connected PV systems was 3.5, 5.1, 7.5 and $13 \mathrm{GW}_{\mathrm{p}}$ in 2005, 2006, 2007 and 2008, respectively (Renewable Energy Policy Framework, 2009). EPIA (2008) developed an advanced and a moderate scenario for future growth in global installed PV capacity. The advanced scenario is based on the assumption that continuing and additional market support mechanisms will lead to a dynamic expansion of worldwide PV installed capacity. Under this scenario, average growth rates of $40 \%, 28 \%$ and $18 \%$ were proposed for the periods of 2007-2010, 2011-2020 and 2021-2030, respectively. On the other hand, the moderate scenario envisages the development of PV against the background of a lower level of political commitment. Average growth rates of
$30 \%, 21 \%$ and $12 \%$ were proposed for the same periods, respectively. Annual installed PV capacity would therefore be 2.4, 6.9, 56 and $281 \mathrm{GW}_{\mathrm{p}}$ for the advanced scenario and 2.4, 5.3, 35 and $105 \mathrm{GW}_{\mathrm{p}}$ for the moderate scenario in 2007, 2010, 2020 and 2030, respectively.

Figs. 3 and 4 show projected values for global annual installed PV capacity and costs for the moderate and advanced scenarios, respectively. The two scenarios were used to estimate future costs of PV modules until 2030. Under the moderate scenario, the cost of PV modules per $\mathrm{kW}_{\mathrm{p}}$ drops from $€ 4600, € 5700$ and $€ 6800$ in 2009 to $€ 2058, € 2550$ and $€ 3042$, respectively, for a learning rate of $15 \%$ and to $€ 1108, € 1373$ and $€ 1638$, respectively, for a learning rate of $25 \%$ in 2030 . Under the advanced scenario, the cost of PV modules per $\mathrm{kW}_{\mathrm{p}}$ drops from $€ 4600, € 5700$ and $€ 6800$ in 2009 to $€ 1687, € 2091$ and $€ 2494$, respectively, for a learning rate of $15 \%$ and to $€ 779$, $€ 966$ and $€ 1152$, respectively, for a learning rate of $25 \%$ in 2030 .

\subsection{Electricity cost trend}

Electricity domestic general rate in Ireland increased from $9.5 €$ cents/kWh in 1989 to $18.1 €$ cents/kWh in October 2008 and then dropped to $16.0 €$ cents/kWh in 2009 (Sustainable Energy Ireland, 2008a). This represented an annual average escalation of $0.43 €$ cents/kWh (4.5\%). However, a linear best fit trend on the electricity general domestic rate data from 1989 to 2009 gives the projected cost shown in Fig. 5.

\subsection{Economic analysis}

The economic analysis presented in this paper assumes that it would be economically viable to invest in a grid connected PV system when the net present value is positive. The net present value (NPV) is the sum of discounted single and annual cash flows over the service life of the PV system less the initial capital cost. It is an indicator of the PV system's worth, with a positive value signifying that benefits accrued will exceed costs over its economic life. The higher the NPV, the greater the financial benefit with an NPV greater than zero indicating a profitable investment (Rogers, 2001; Twidell and Weir, 2006).

This study is based on PV system performance, solar radiation and market data for Dublin, Ireland. Values used in the analysis

Fig. 3. PV module cost and global annual installed capacity against year of installation for the moderate scenario. 


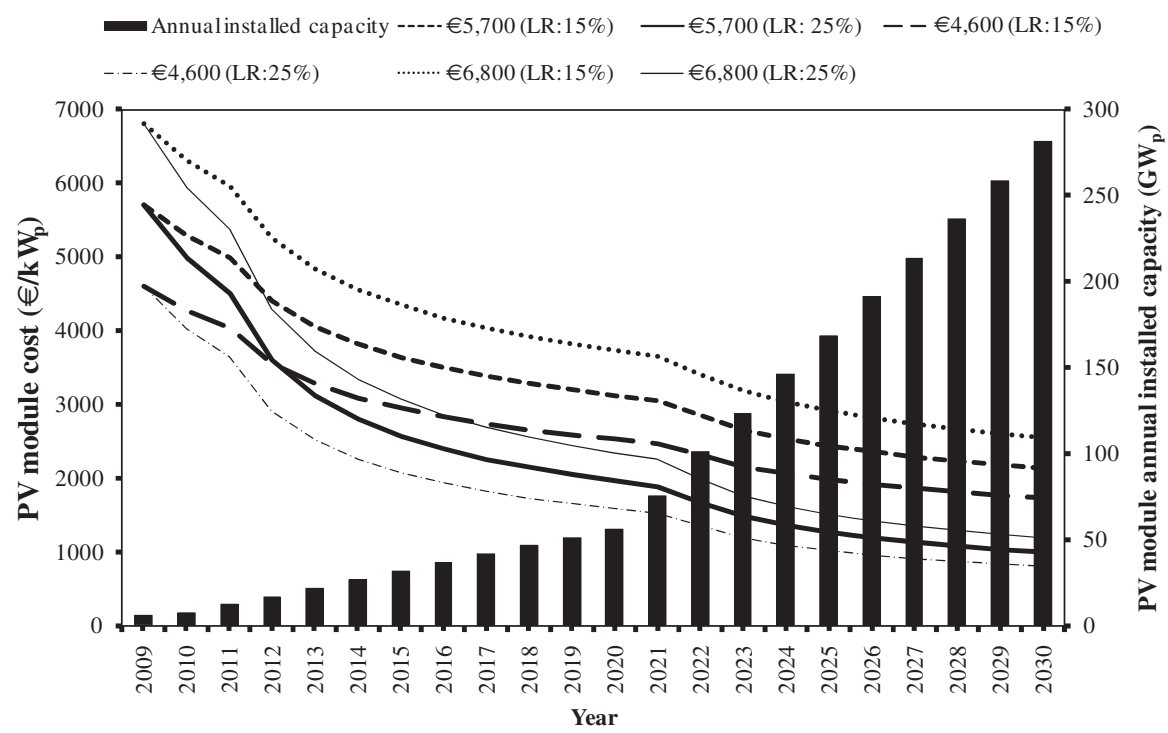

Fig. 4. PV module cost and global annual installed capacity against year of installation for the advanced scenario.

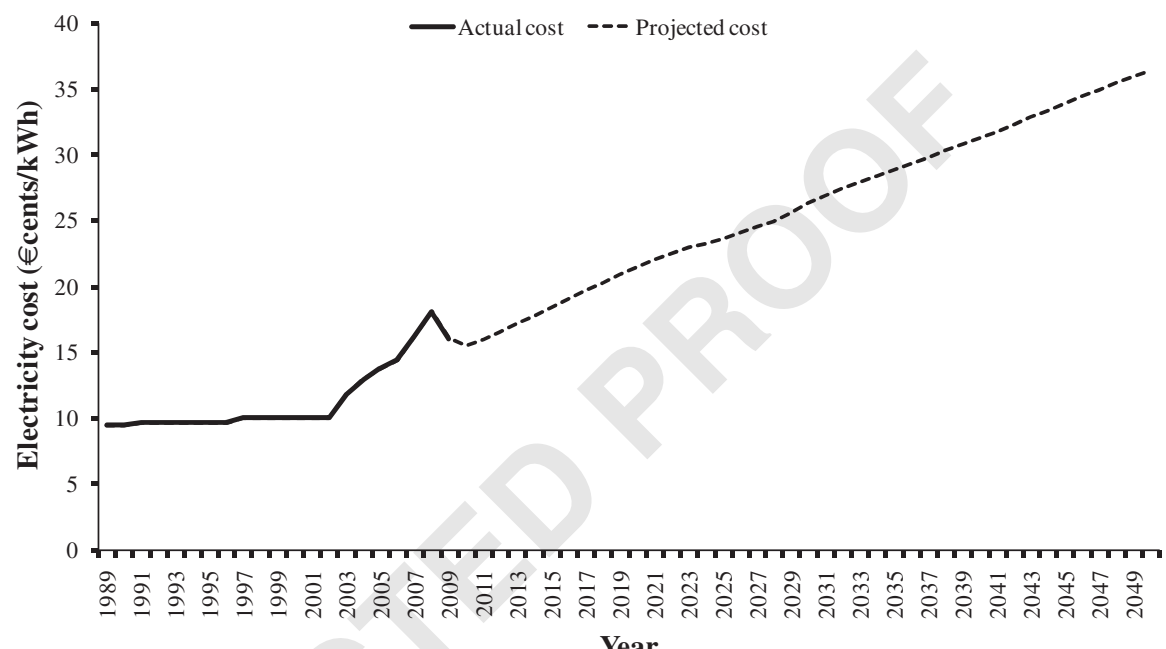

Year

Fig. 5. Electricity general domestic rate and projections in Ireland from 1989 to 2050.

are shown in Table 1. The PV used in this analysis had a capacity of $1.72 \mathrm{~kW}_{\mathrm{p}}$ and generated $885.1 \mathrm{kWh} / \mathrm{kW}_{\mathrm{p}}$ during its first year of operation. The average annual electricity consumption of a representative domestic dwelling in Ireland is $5591 \mathrm{kWh}$. An analysis run on the daily energy generated by the PV system on 15 min interval and the energy demand profile for the representative dwelling revealed that over a year, $96 \%$ of the energy generated will be consumed on-site while $4 \%$ will be exported to the grid. Over the lifespan of the PV modules, exposure to ultraviolet radiation would lead to degradation of power output. A study conducted by Osterwald et al. (2002) showed a linear dependence of maximum power degradation of $0.82 \%$ per year for mono-crystalline $\mathrm{Si}$ modules due to exposure to ultraviolet radiation.

\subsubsection{Performance ratio}

The performance ratio $(Q)$ indicates the overall effect of losses on a PV array's normal power output depending on array temperature and incomplete utilization of incident solar radiation and system component inefficiencies or failures. The PR of a PV system indicates how close it approaches ideal performance during real operation and allows comparison of PV systems independent of location, tilt angle, orientation and their nominal rated power capacity (Blaesser, 1997). Performance ratio is defined by the following equations as (Eicker, 2003; Nakagami et al., 2003):

$Q=\frac{\eta_{\text {sys }}}{\eta_{\mathrm{STC}}}=\frac{E_{\mathrm{AC}}}{G_{t}} \frac{G_{\mathrm{STC}}}{E_{\mathrm{DC}, \mathrm{STC}}}$

where, $\eta_{\text {sys }}$ is the system efficiency (\%); $\eta_{\text {STC }}$ the efficiency under standard test conditions (\%); $E_{\mathrm{AC}}$ the AC energy output (kWh); $E_{\mathrm{DC}, \mathrm{STC}}$ the DC energy output under standard test conditions $(\mathrm{kWh}) ; G_{t}$ the total in-plane solar radiation; $G_{\mathrm{STC}}$ the total solar radiation under standard test conditions.

\subsubsection{Net present value}

The present value of total cost of the PV system is the sum of the present value of costs associated with the PV module, initial BOS, replacement cost of BOS and variable cost. It is assumed that 
money used to buy the PV modules and BOS components are obtained from a bank loan. The total life cycle cost of the PV system $\left(C_{t}\right)$ is given as (Bhandari and Stadler, 2009)

$C_{t}=C_{\mathrm{mt}}+C_{\mathrm{BOS}}+C_{\mathrm{BOSrep}}+C_{v}$

and written as

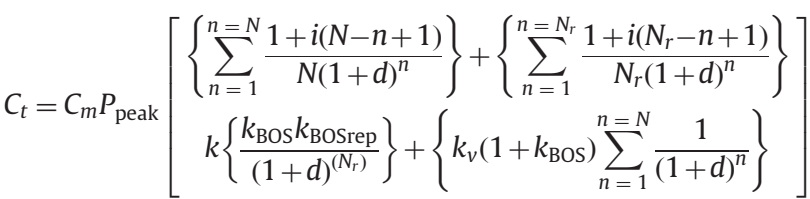

The PV module price reduction factor $(k)$ is given as

$k=\frac{C_{m\left(n+N_{r}\right)}}{C_{m(n)}}$

where $C_{t}$ is the total PV system cost $(€) ; C_{\mathrm{mt}}$ the present value of cost associated with PV module $\left(\epsilon_{2009}\right) ; C_{\mathrm{BOS}}$ the present value of cost associated with the initial investment on BOS $\left(\epsilon_{2009}\right)$; $C_{\mathrm{BOSrep}}$ the present value of BOS replacement cost $\left(\epsilon_{2009}\right) ; C_{v}$ the present value of total variable cost $\left(€_{2009}\right) ; \mathrm{GHG}_{\mathrm{EF}}$ the greenhouse gas emission factor.

The present value of total revenue from the system during its useful life is the sum of the present value of revenue of PV generated electricity consumed on-site and the present value of revenue of electricity exported to the grid. The size of the PV system and the electricity demand profile determine the quantity of electricity it generates that is used on-site to displace grid supplied electricity at a cost of $P_{\mathrm{el}, \mathrm{im}}$ for a given year. The present value of total revenue $\left(R_{t}\right)$ of the PV system is given as

$R_{t}=P_{\text {peak }} Q \frac{G_{m}}{I_{\mathrm{STC}}}\left[P_{\mathrm{el}, \mathrm{im}} E_{\mathrm{on}} \sum_{n=1}^{n=N} \frac{\left(1+n r_{\text {im }}\right)(1-s)^{n-1}}{(1+d)^{n}}\right.$

$$
\left.+P_{\mathrm{el}, \mathrm{ex}}\left(1-E_{\mathrm{on}}\right) \sum_{n=1}^{n=N} \frac{\left(1+n r_{\mathrm{ex}}\right)(1-s)^{n-1}}{(1+d)^{n}}\right]
$$

The net present value (NPV) of the PV system is given as

$\mathrm{NPV}=R_{t}-C_{t}$

\subsubsection{PV electricity cost}

The cost of electricity generated $\left(C_{E}\right.$ in $\left.€ / \mathrm{kWh}\right)$ is the ratio of the life cycle cost of the PV system to the total power output from the PV system over its service life and is given as

$C_{E}=\frac{C_{t}}{E_{n}}$

The total power output ( $E_{n}$ in $\mathrm{kWh}$ ) by the PV system over its service life is given as

$E_{n}=P_{\text {peak }} Q \frac{G_{m}}{I_{\text {STC }}} \sum_{n=1}^{N}(1-S)^{n-1}$

\subsection{Greenhouse gas emission analysis}

$\mathrm{CO}_{2}$ emissions associated with electricity generation in Ireland dropped from $0.728 \mathrm{~kg} \mathrm{CO}_{2} / \mathrm{kWh}$ in 2005 to $0.644 \mathrm{~kg} \mathrm{CO}_{2} / \mathrm{kWh}$ in 2006 and then $0.538 \mathrm{~kg} \mathrm{CO}_{2} / \mathrm{kWh}$ in 2007 with the introduction of the All-Island Single Electricity Market. This drop in $\mathrm{CO}_{2}$ emissions was as a result of fuel switching from coal, oil and peat to gas and renewables. In 2007, electricity generation in Ireland was based on coal (18\%), gas (55\%), oil (6\%), peat (6\%), renewables $(11 \%)$ and combined heat and power (4\%) (Electricity Supply Board. Annual Report, 2007). This fuel mix shows that there is still potential for $\mathrm{CO}_{2}$ emission reduction in electricity generation. In order to investigate the effect of decarbonizing electricity generation in Ireland, two scenarios for $\mathrm{CO}_{2}$ emissions

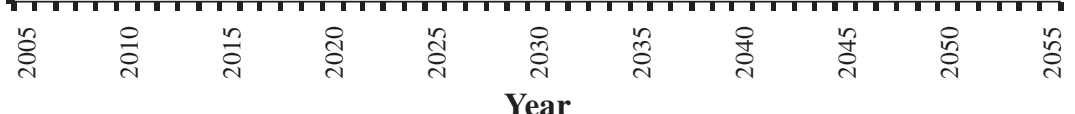

Fig. 6. Actual and projected $\mathrm{CO}_{2}$ emissions associated with grid-supplied electricity in Ireland.

Table 2

Parameters for GHG emission analysis.

\begin{tabular}{|c|c|c|c|}
\hline Description & Unit & Symbol & Value \\
\hline Grid transmission and distribution losses & $\%$ & $L_{\text {grid,TD }}$ & 9 \\
\hline
\end{tabular}


reduction were considered in this study namely: 25\% and 50\% reduction of 2007 emissions between 2007 and 2055 when a PV system with a service life of 25 years installed in 2030 will be decommissioned as shown in Fig. 6.

Table 2 shows the parameters used to calculate the quantity of avoided $\mathrm{CO}_{2}$ emissions by the PV system. Avoided $\mathrm{CO}_{2}$ emissions associated with grid supplied electricity are essentially those displaced by PV generated electricity used on-site. On the other hand, avoided $\mathrm{CO}_{2}$ emissions associated with PV generated

\begin{tabular}{c|c|c|}
\multicolumn{2}{c}{} & \multicolumn{2}{c}{ Global PV market growth } \\
\cline { 3 - 3 } & \multicolumn{1}{c}{ Moderate } & \multicolumn{1}{c}{ Advanced } \\
\cline { 2 - 3 } Learning $25 \%$ & 'Moderate 25' & 'Advanced 25' \\
\cline { 2 - 3 } Rate $15 \%$ & 'Moderate 15' & 'Advanced 15' \\
\cline { 2 - 3 } & &
\end{tabular}

Fig. 7. PV learning rate and global growth scenarios. electricity exported to the grid are reduced by the distribution losses on the low voltage distribution lines since this electricity ends up within the PV system's neighbourhood.

\subsubsection{Avoided greenhouse gas emissions}

PV systems produce electricity in a $\mathrm{CO}_{2}$ neutral way during their service life although some $\mathrm{CO}_{2}$ emissions arise during the production of PV modules and other equipment. In this study the embodied emissions due to the production of the PV system components are neglected since the components are not manufactured in Ireland and do not therefore affect national $\mathrm{CO}_{2}$ emission figures. The total quantity of avoided greenhouse gas emissions $\left(\mathrm{GHG}_{\text {avoided }}\right.$ in $\mathrm{kg} \mathrm{CO} / \mathrm{kWh}$ ) during the PV system's service life is the sum of avoided emissions due to the quantity of displaced grid-supplied electricity by the PV system used on-site (including transmission and distribution losses) plus the quantity of avoided emissions due to electricity exported to the low
Fig. 8. Net present value and electricity generation cost against PV module cost under different scenarios. Life cycle electricity production costs $(€ / \mathrm{kWh})$ are shown in parenthesis.

Fig. 9. Net present value for different years of installation under different scenarios for PV module cost of $€ 4600$ per $k W_{p}$. 
voltage grid (including distribution losses). It is calculated using Eq. (11) given as

$$
\begin{aligned}
G H G_{\text {avoided }}= & P_{\text {peak }} Q \frac{G_{m}}{I_{\mathrm{STC}}} \sum_{n=1}^{N}(1-S)^{n-1} \mathrm{GHG}_{\mathrm{EF}, n}\left[E_{\text {on }}\left(1+L_{\text {grid,TD }}\right)\right. \\
& \left.+\left(1-E_{\mathrm{on}}\right)\left(1+L_{\text {grid, } \mathrm{TD}}-L_{\mathrm{PV}, \mathrm{D}}\right)\right]
\end{aligned}
$$

\subsubsection{Greenhouse gas emissions abatement cost}

The total cost of greenhouse gas emissions abatement $\left(C_{\mathrm{GHG}}\right)$ is calculated using the negative values of NPV which indicate the amount of money required to make the investment on the PV system economically viable. It is calculated using Eq. (12) given as

$C_{\mathrm{GHG}}=\frac{\mathrm{NPV}}{\mathrm{GHG}_{\mathrm{avoided}}}$

\section{Results and discussion}

Four scenarios were developed to model the effect of PV module cost reduction based on a moderate and advanced growth in annual installed global PV capacity and a learning rate of either System NPVs and life cycle electricity generation costs were calculated for the four scenarios based on the PV system costs and a system lifespan of 25 years.

\subsection{PV system installed in 2009}

Fig. 8 shows system NPVs and electricity generation costs against PV module costs under the different scenarios for PV systems installed in 2009. It can be seen that NPVs decrease with PV module costs for a given scenario. The values in brackets represent the life cycle costs of electricity generation in $€ / \mathrm{kWh}$. $15 \%$ or $25 \%$ (i.e. $20 \% \pm 5 \%$ ). The scenarios are illustrated in Fig. 7 .

67

69

Fig. 10. Net present value for different years of installation under different scenarios for PV module cost of $€ 5700$ per $\mathrm{kW}_{\mathrm{p}}$.

Fig. 11. Net present value against year of installation under different scenarios for PV module cost of $€ 6800$ per $k W_{p}$. 
Electricity generation costs also decrease with increases in learning rates for a given PV module price. However, electricity generation costs which increase with PV module cost are lower for the advanced scenarios than the moderate scenarios while holding learning rates constant.

The system's NPV reduces from $-€ 10,173$ for PV module cost of $€ 4600$ per $\mathrm{kW}_{\mathrm{P}}$ to $-€ 18,718$ per $\mathrm{kW}_{\mathrm{p}}$ for the Advanced 25 and Moderate 15 scenarios, respectively. The negative NPVs showed that investment in the PV system in 2009 was not economically viable. The average cost of PV electricity generation was $0.47,0.58$ and $0.70 € / \mathrm{kWh}$ for PV module costs of $€ 4600, € 5700$ and $€ 6800$ per $\mathrm{kW}_{\mathrm{p}}$, respectively.

\subsection{Net present value and electricity cost projections}

The negative NPV values for the PV system installed in 2009 presented in Section 4.1 show that at present it is not economically viable to invest in the PV system under the conditions assumed in this study. However, the cost reduction potential of PV modules due to market growth, learning by doing and technological developments (resulting in a learning rate of $20 \pm 5 \%$ ) together with the likely long-term increase in the value of electricity assumed to be (4.5\% per annum) has the effect of improving the NPV for systems installed post 2009. Therefore, the future values of NPV and life cycle electricity generation costs for systems installed after 2009 were calculated for each of the scenarios (see Fig. 7) and capital cost projections (see Figs. 3 and 4). Results obtained show that the NPV increases with year of investment and systems become economically viable under some scenarios and PV module costs within the time horizon analysed (up to 2030). The negative values of NPV indicate the level of additional capital support required to make investment in the PV system economically viable. The support required decreases as the year of investment increases beyond 2009.

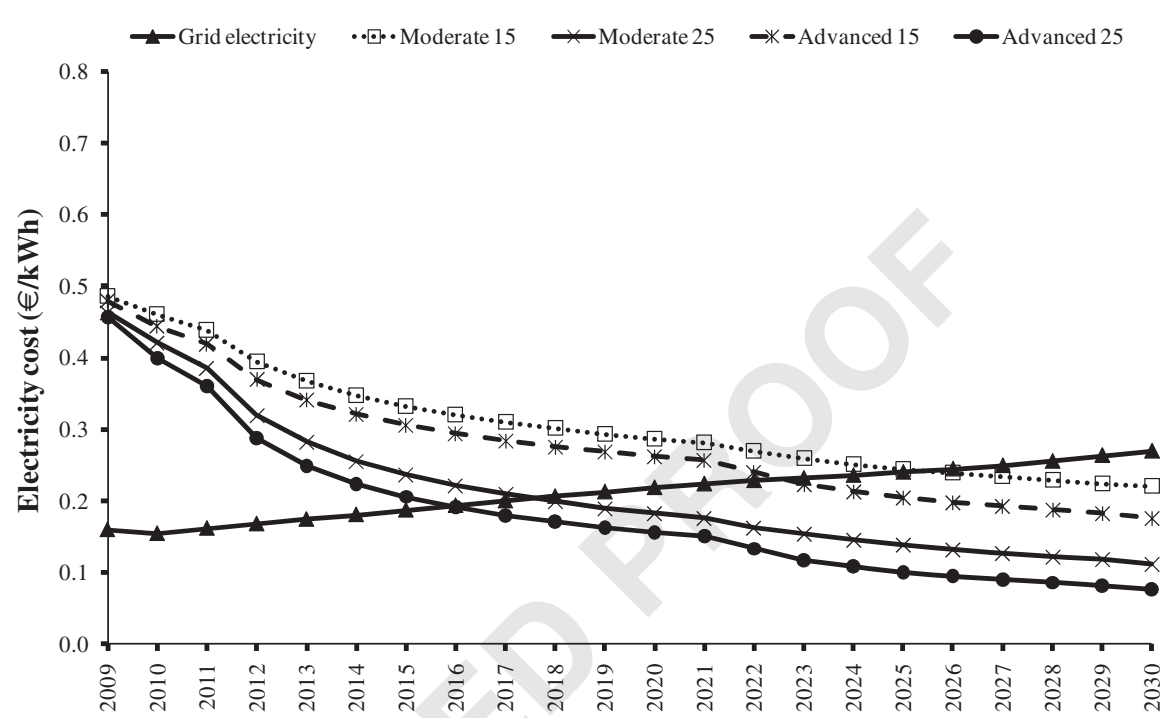

Year of installation

Fig. 12. PV-generated and grid-supplied electricity cost against year of installation under different scenarios for PV module cost of $€ 4600$ per $k W_{p}$.

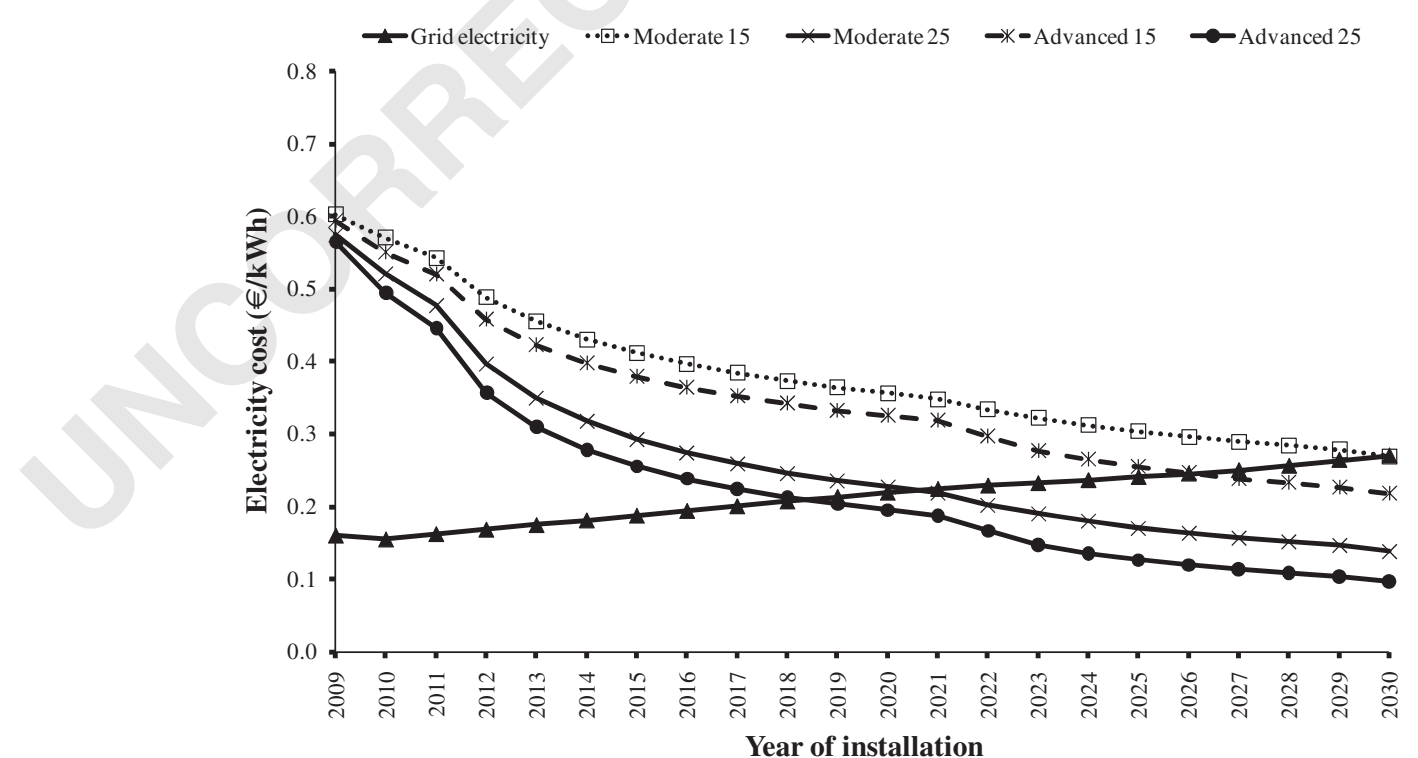

Fig. 13. PV-generated and grid-supplied electricity cost against year of installation under different scenarios for PV module cost of $€ 5700$ per $k W_{p}$. 
10

\subsubsection{Net present value}

Figs. 9-11 show variation in NPV against year of installation under different scenarios for initial (2009) PV module costs of $€ 4600$, $€ 5700$ and $€ 6800$ per $\mathrm{kW}_{\mathrm{p}}$, respectively. Fig. 9 shows that for an initial PV module cost of $€ 4600$ per $\mathrm{kW}_{\mathrm{p}}$, the investment would be economically viable under the Advanced 15, Moderate 25 and Advanced 25 scenarios in 2030, 2023 and 2021, respectively. Fig. 10 shows that for an initial PV module cost of $€ 5700$ per $\mathrm{kW}_{\mathrm{p}}$, the investment would be economically viable under the Moderate 25 and Advanced 25 scenarios in 2026 and 2023, respectively. Fig. 11 shows that for an initial PV module cost of $€ 6800$ per $\mathrm{kW}_{\mathrm{p}}$, the investment would be economically viable under the Moderate 25 and Advanced 25 scenarios in 2029 and 2024, respectively.

\subsubsection{Electricity cost}

Figs. 12-14 show variations in PV-generated and grid-supplied electricity costs against year of installation under different scenarios for PV module costs of $€ 4600, € 5700$ and $€ 6800$ per
kW . Fig. 12 shows that for an initial PV module cost of $£ 4600$ per $\mathrm{kW}_{\mathrm{p}}$, the life cycle cost of PV generated electricity drops from between 0.46 and $0.49 € / \mathrm{kWh}$ in 2009 to between 0.08 and $0.27 € / \mathrm{kWh}$ in 2030 . Grid parity is projected to occur in 2026, 2023, 2018 and 2016 for the Moderate 15, Advanced 15, Moderate 25 and Advanced 25 scenarios, respectively.

Fig. 13 shows that for an initial PV module cost of $£ 5700$ per $\mathrm{kW}_{\mathrm{p}}$, the life cycle cost of PV generated electricity drops from between 0.57 and $0.60 € / \mathrm{kWh}$ in 2009 to between 0.10 and $0.27 € /$ $\mathrm{kWh}$ in 2030. Grid parity is projected to occur in 2028, 2024, 2019 and 2017 for the Moderate 15, Advanced 15, Moderate 25 and Advanced 25 scenarios, respectively.

Fig. 14 shows that for an initial PV module cost of $€ 6800$ per $\mathrm{kW}_{\mathrm{p}}$, the life cycle cost of PV generated electricity drops from between 0.67 and $0.72 € / \mathrm{kWh}$ in 2009 to between 0.11 and $0.32 € /$ $\mathrm{kWh}$ in 2030. Grid parity is projected to occur in 2030, 2023 and 2021 for the Advanced 15, Moderate 25 and Advanced 25 scenarios, respectively.
Year of installation

Fig. 14. PV-generated and grid-supplied electricity cost against year of installation under different scenarios for PV module cost of $€ 6800$ per $\mathrm{kW}_{\mathrm{p}}$. 


\subsection{Avoided greenhouse gas emissions}

Fig. 15 shows avoided total life cycle $\mathrm{CO}_{2}$ emissions against year of installation for a $25 \%$ and $50 \%$ projected reduction in grid-supplied electricity emissions between 2007 and 2055. The results show a reduction in the quantity of avoided $\mathrm{CO}_{2}$ emissions due to the projected reduction in GHG emissions associated with electricity generation. It is seen that the total quantity of avoided $\mathrm{CO}_{2}$ emissions for the PV system installed in 2009 reduces from 10.4 and $9.7 \mathrm{tCO}_{2} / \mathrm{kW}_{\mathrm{p}}$ for the $25 \%$ and $50 \%$ cases, respectively, to 7.8 and $6.3 \mathrm{tCO}_{2} / \mathrm{kW}_{\mathrm{p}}$ if the PV system was installed in 2030 . This shows that reducing the intensity of GHG emissions associated with the generation of grid supplied electricity reduces the attractiveness of $\mathrm{PV}$ systems in mitigating $\mathrm{CO}_{2}$ emissions.

\subsection{Greenhouse gas abatement cost}

Figs. 16-18 show variations in $\mathrm{CO}_{2}$ emissions abatement costs against year of installation for a $25 \%$ and $50 \%$ projected $\mathrm{CO}_{2}$ emission reduction and initial PV module costs of $£ 4600, € 5700$ and $€ 6800$ per $\mathrm{kW}_{\mathrm{p}}$. It can be seen that $\mathrm{CO}_{2}$ abatement costs decrease for all scenarios with increasing year of installation; abatement costs also decrease with decreasing PV module installation costs. In the best case, no subsidies are required from 2021 onwards.

Fig. 16 shows $\mathrm{CO}_{2}$ emissions abatement costs against year of installation for an initial PV module cost of $£ 4600$ per $\mathrm{kW}_{\mathrm{p}}$ for both a 25\% and 50\% reduction in the $\mathrm{CO}_{2}$ intensity of electricity production by 2055 . In the case of a $25 \%$ reduction in $\mathrm{CO}_{2}$ emissions, abatement costs decrease from between $€ 569$ and $523 € / \mathrm{tCO}_{2}$ in 2009 to between 230 and $\mathrm{\ell} € / \mathrm{tCO}_{2}$ in 2020 and to between 55 and $0 € / \mathrm{tCO}_{2}$ in 2030; costs are higher for the Moderate 15 scenario in all cases. For 50\% reduction in $\mathrm{CO}_{2}$ emissions, abatement costs decrease from between 624 and $569 € / \mathrm{tCO}_{2}$ in 2009 to between 269 and $0 € / \mathrm{tCO}_{2}$ in 2020 and finally to between 70 and $0 € / \mathrm{tCO}_{2}$ in 2030; again costs are highest for the Moderate 15 scenario.

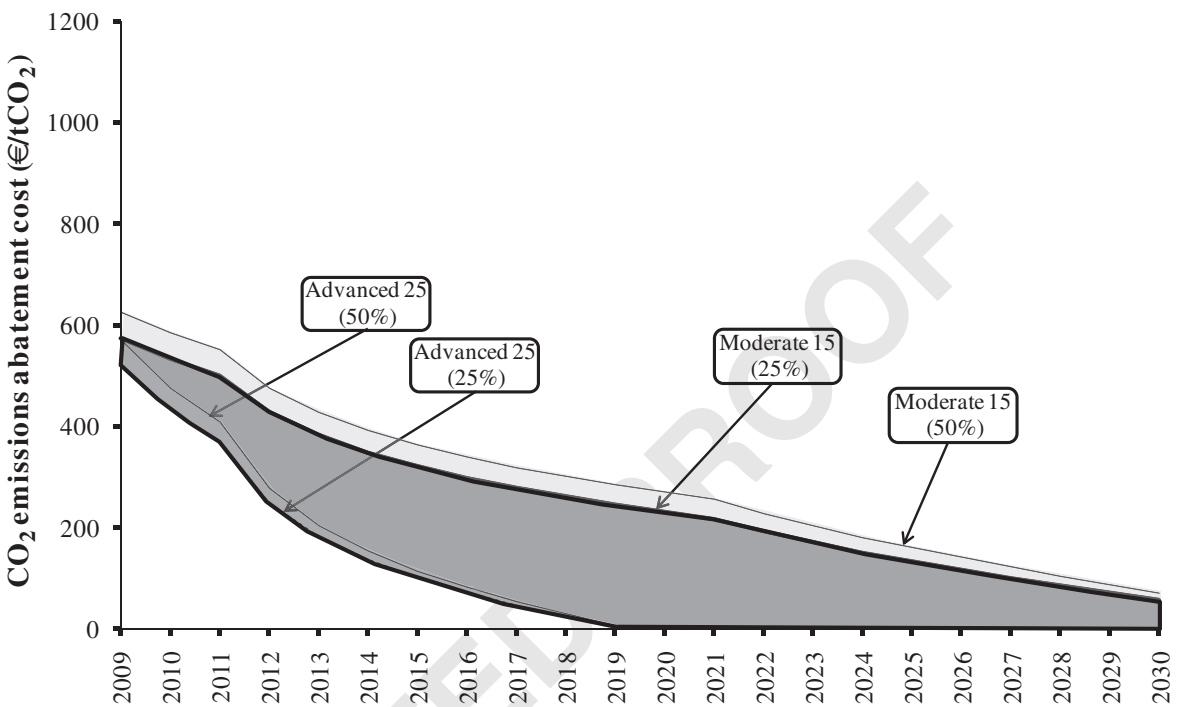

\section{Year of installation}

Fig. 16. $\mathrm{CO}_{2}$ emissions abatement cost against year of installation for $25 \%$ and $50 \%$ projected $\mathrm{CO}_{2}$ emission reduction and an initial $\mathrm{PV}$ module cost of $€ 4600$ per $\mathrm{kW}$.

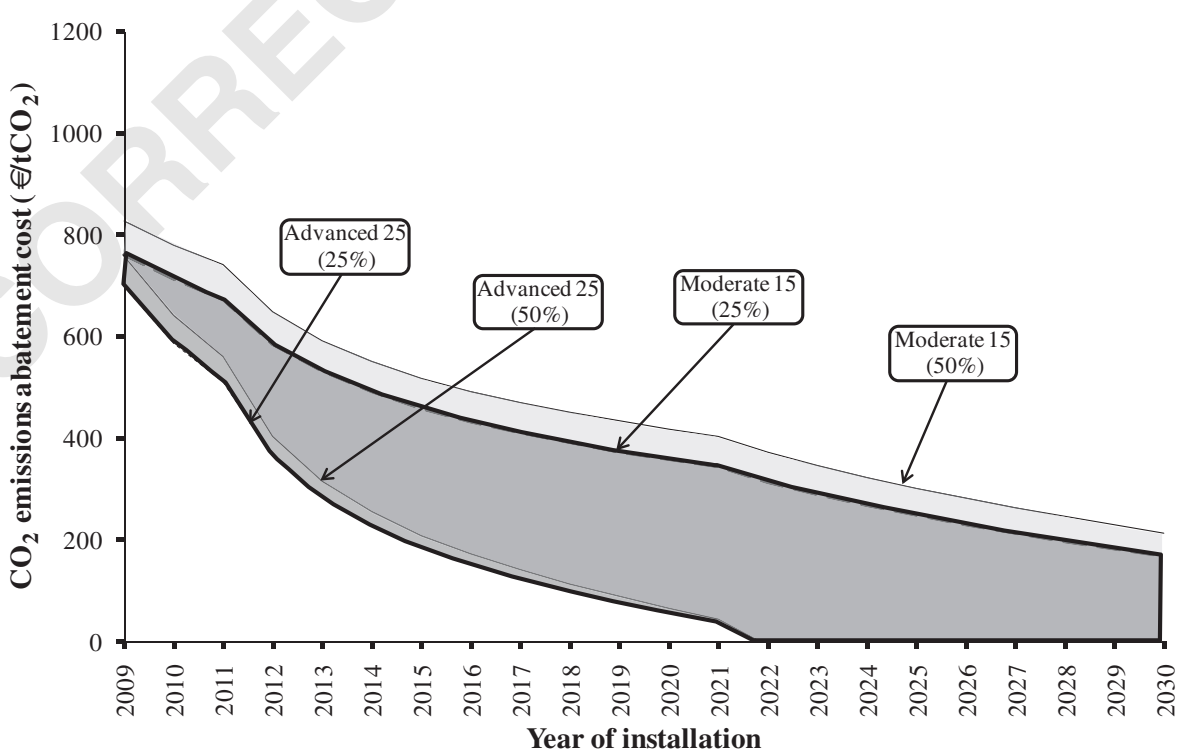

Fig. 17. $\mathrm{CO}_{2}$ emissions abatement cost against year of installation for $25 \%$ and $50 \%$ projected $\mathrm{CO}_{2}$ emission reduction and an initial $\mathrm{PV}$ module cost of $€ 5700$ per $\mathrm{kW}$. 


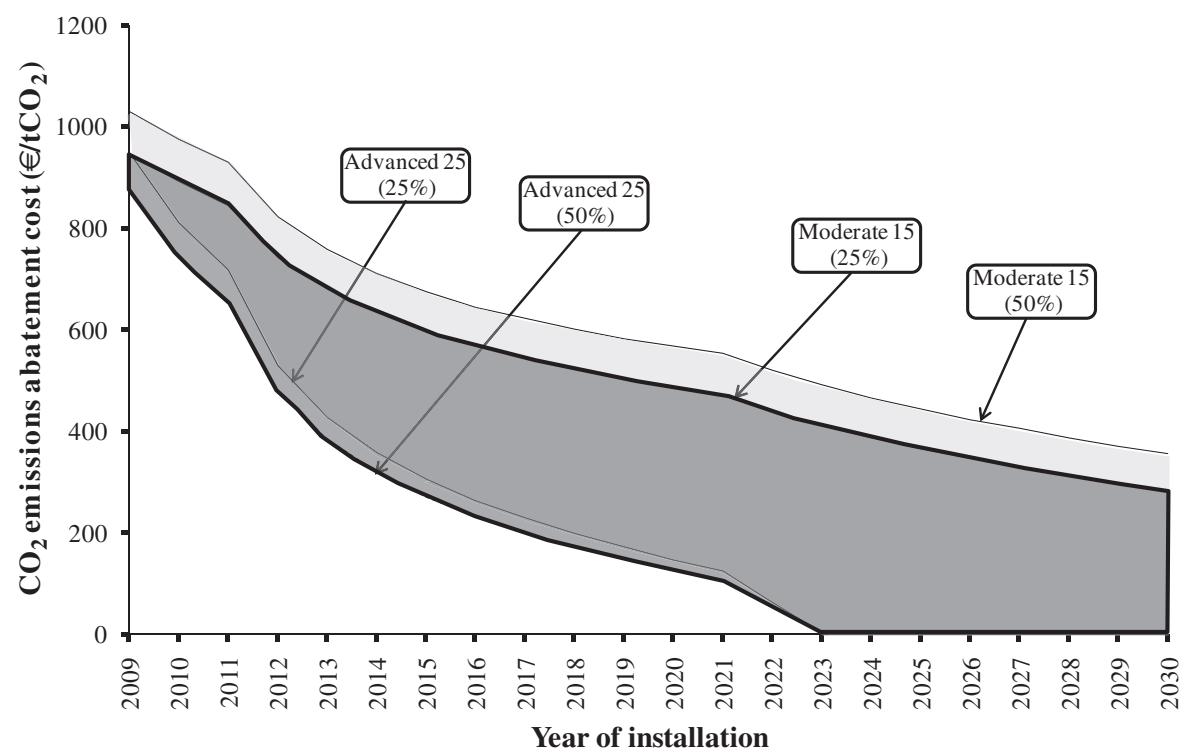

Fig. 18. $\mathrm{CO}_{2}$ emissions abatement cost against year of installation for $25 \%$ and $50 \%$ projected $\mathrm{CO}_{2}$ emission reduction and an initial $\mathrm{PV}$ module cost of $€ 6800$ per $\mathrm{kW}$

Fig. 17 shows $\mathrm{CO}_{2}$ emissions abatement costs against year of installation for an initial PV module cost of $€ 5700$ per $\mathrm{kW}_{\mathrm{p}}$ for both a $25 \%$ and $50 \%$ reduction in the $\mathrm{CO}_{2}$ intensity of electricity production by 2055 . In the case of a $25 \%$ reduction in $\mathrm{CO}_{2}$ emissions, abatement costs decrease from between 759 and $697 € / \mathrm{tCO}_{2}$ in 2009 to between 358 and $56 € / \mathrm{tCO}_{2}$ in 2020 and to between 168 and $0 € / \mathrm{tCO}_{2}$ in 2030; costs are higher for the Moderate 15 scenario in all cases. For $50 \%$ reduction in $\mathrm{CO}_{2}$ emissions, abatement costs decrease from between 827 and $759 € / \mathrm{tCO}_{2}$ in 2009 to between 418 and $65 € / \mathrm{tCO}_{2}$ in 2020 and finally to between 213 and $0 € / \mathrm{tCO}_{2}$ in 2030; again costs are highest for the Moderate 15 scenario.

Fig. 18 shows $\mathrm{CO}_{2}$ emissions abatement costs against year of installation for an initial PV module cost of $€ 6800$ per $\mathrm{kW}_{\mathrm{p}}$ for both a $25 \%$ and $50 \%$ reduction in the $\mathrm{CO}_{2}$ intensity of electricity production by 2055 . In the case of a $25 \%$ reduction in $\mathrm{CO}_{2}$ emissions, abatement costs decrease from between 948 and $871 € / \mathrm{tCO}_{2}$ in 2009 to between 485 and $125 € / \mathrm{tCO}_{2}$ in 2020 and to between 281 and $0 € / \mathrm{tCO}_{2}$ in 2030; costs are higher for the Moderate 15 scenario in all cases. For $50 \%$ reduction in $\mathrm{CO}_{2}$ emissions, abatement costs decrease from between 1030 and $948 € / \mathrm{tCO}_{2}$ in 2009 to between 568 and $146 € / \mathrm{tCO}_{2}$ in 2020 and finally to between 356 and $0 € / \mathrm{tCO}_{2}$ in 2030; again costs are highest for the Moderate 15 scenario.

\subsection{Comparative analysis}

Table 3 shows projected costs for PV electricity generation for rooftop system in different locations (European Photovoltaic Industry Association and Green Peace 2008). Current life cycle electricity generation costs for Dublin are at least 50\% higher than equivalent locations in Europe (Berlin and Paris). The disparity in electricity generation costs however decreases somewhat after 2010.

\section{Conclusion}

Results of a study on projected economic and environmental performance of a $1.72 \mathrm{~kW}_{\mathrm{p}}$ pilot trial rooftop mounted PV system in Dublin, Ireland has been presented. Measured performance data was used to evaluate the performance ratio and correct same
Table 3

Projected PV electricity generation costs for rooftop system $(€ / \mathrm{kWh})$.

\begin{tabular}{lcccc}
\hline Location & Sunshine hours & 2010 & 2020 & 2030 \\
\hline Berlin & 900 & 0.35 & 0.20 & 0.13 \\
*Dublin & $\mathbf{9 2 0}$ & $\mathbf{0 . 5 3}$ & $\mathbf{0 . 2 8}$ & $\mathbf{0 . 1 8}$ \\
Paris & 1000 & 0.31 & 0.18 & 0.12 \\
Washington & 1200 & 0.28 & 0.15 & 0.10 \\
Hong kong & 1300 & 0.24 & 0.14 & 0.09 \\
Sydney/Buenos & 1400 & 0.22 & 0.13 & 0.08 \\
Aires/Bombay/Madrid & & & & \\
Bangkok & 1600 & 0.20 & 0.11 & 0.07 \\
Los Angeles/Dubai & 1800 & 0.17 & 0.10 & 0.07 \\
\hline
\end{tabular}

* Current study.

using long-term solar radiation data. Measured PV output was used to dynamically evaluate the quantity of electricity generated by the PV system that would be used on-site relative to a $15 \mathrm{~min}$ average electricity demand profile for domestic dwellings in Ireland with annual average consumption of $5591 \mathrm{kWh}$. It was determined that $96 \%$ of the energy generated would be used onsite with only $4 \%$ available for export. Over an estimated useful service life of 25 years, an annual average of $759 \mathrm{kWh} / \mathrm{kW}_{\mathrm{p}}$ of electricity would be generated by the PV system with output loss due to UV degradation accounting for $9.2 \%$ of total generation assuming no losses.

An average PV module installed cost of $5700 \pm 1100 € / \mathrm{kW}_{\mathrm{p}}$ obtained from a survey of 16 systems installed in 2009 was used. A current feed-in tariff of $0.19 € / \mathrm{kWh}$ was used which assumed to remain constant throughout the analysis period. Grid supplied electricity was projected to increase linearly at an annual rate of $4.5 \%$ based on 20 years of historic data. Four scenarios for PV module cost growth were developed based on PV module learning rates of $15 \%$ and $25 \%$ as well as a moderate and an advanced global PV market growth. The quantity of GHG emissions avoided and GHG abatement costs were evaluated assuming a $25 \%$ and $50 \%$ reduction in GHG emissions associated with grid-supplied electricity between 2007 and 2065. The economic and environmental performance of the PV system was evaluated for years of installation between 2009 and 2030 inclusive assuming a 25 year lifespan (with production up to 2055). 
Results obtained showed that domestic grid-supplied electricity cost is projected to grow from $0.16 € / \mathrm{kWh}$ in 2009 to $0.27 € / \mathrm{kWh}$ in 2030 and $0.45 € / \mathrm{kWh}$ in 2065. PV generated electricity costs decrease from 0.60 and $0.57 € / \mathrm{kWh}$ in 2009 to 0.27 and $0.10 € / \mathrm{kWh}$ in 2030 for the Moderate 15 and Advanced 25 scenarios, respectively. Grid parity would then occur in 2030 and 2019 for the Moderate 15 and Advanced 25 scenarios, respectively. The system NPVs increase from $-€ 14,926$ and $-€ 13,734$ in 2009 to $-€ 2971$ and $€ 2731$ for the Moderate 15 and Advanced 25 scenarios, respectively, during the same period. The corresponding normalized NPVs would therefore increase from -8678 and $-7985 € / \mathrm{kW}_{\mathrm{p}}$ in 2009 to -1727 and $1588 € / \mathrm{kW}_{\mathrm{p}}$ respectively. For all four scenarios considered, the average PV generated electricity costs drop from 0.58 to $0.18 € / \mathrm{kWh}$ while the average NPV increases from $-€ 14,330$ to $-€ 35$ if the PV system is installed in 2009 and 2030, respectively. The normalized average NPV increases from -8331 to $-20 € / \mathrm{kW}_{\mathrm{p}}$ for PV systems installed in 2009 and 2030, respectively. Grid parity then occurs in 2024. The total quantity of avoided $\mathrm{CO}_{2}$ emissions for the PV system installed in 2009 reduces from 10.4 and $9.7 \mathrm{tCO}_{2} / \mathrm{kW}_{\mathrm{p}}$ for the $25 \%$ and $50 \%$ cases, respectively, to 7.8 and $6.3 \mathrm{tCO}_{2} / \mathrm{kW}_{\mathrm{p}}$ if the PV system was installed in 2030. The life cycle cost of $\mathrm{CO}_{2}$ abatement drops from between 523 and $1030 € / \mathrm{tCO}_{2}$ in 2009 to between 0 and $568 € /$ $\mathrm{tCO}_{2}$ in 2020 and finally to between 0 and $356 € / \mathrm{tCO}_{2}$ in 2030 .

A comparative analysis shows that current PV system costs are at least 50\% higher in Ireland than other jurisdictions with similar climatic conditions. This suggests that the market is not operating optimally, possibly due to the low numbers of buyers and sellers or due to a lack of market information such as system price and quality. Significant decreases in capital costs might occur, therefore, if many buyers and sellers entered the market and information were more freely available. This would require market intervention such as subsidies (e.g. grants or low cost loans), higher feed-in tariffs, or regulation. However with a current marginal cost of abatement of between 523 and $1030 € / \mathrm{tCO}_{2}$, widespread deployment would be costly and would not represent best value for money for the taxpayer.

\section{References}

Bhandari, R., Stadler, I., 2009. Grid parity analysis of solar photovoltaic systems in Germany using experience curves. Solar Energy 83 (9), 1634-1644.

Blaesser, G., 1997. PV system measurements and monitoring the European experience. Solar Energy Materials and Solar Cells 47 (1-4), 167-176.

Department of Environment Heritage and Local Government, 2009. People power. 〈http://www.dcenr.gov.ie/Press + Releases/People + power+-+Minister+Rya $\mathrm{n}+$ announces + incentives + for + micro-generation.htm $>$ (accessed on 20/03/ 2009).

Eicker, U., 2003. Solar Technologies for Buildings.. John Wiley and Sons, England. Electricity Supply Board. Annual Report 2007: ESB power generation review. $\langle$ http://www.esb.ie > (accessed on 30/10/2008).

Eurobserv'er, March 2009. Photovoltaic barometer.

EPIA, 2008. Solar generation V. 〈http://www.epia.org 〉 (accessed on 13/12/2008).
Ferioli, F., Schoots, K., et al., 2009. Use and limitations of learning curves for energy technology policy: 수 component-learning hypothesis. Energy Policy 37 (7), 2525-2535.

Nakagami, H., Ishihar, O., et al., 2003. Performance of residential PV system under actual field conditions in wester part of Japan. In: International Solar Energy Conference, Hawaii, USA.

Neij, L., 2008. Cost development of future technologies for power generation-a study based on experience curves and complementary bottom-up assessments. Energy Policy 36 (6), 2200-2211.

Osterwald, C.R., Anderberg, A., et al., May 2002. Degradation analysis of weathered crystalline-silicon PV modules. National Renewable Energy Laboratory, NREL/ CP-520-31455. / http://www.nrel.gov/docs/fy02osti/31455.pdf $>$.

Ren, H., Gao, W., Ruan, Y., 2009. Economic optimization and sensitivity analysis of photovoltaic system in residential buildings. Renewable Energy 34 (3), 883-889.

Renewable Energy Policy Framework (REN21), 2009. Renewables global status report: 2009 update. Paris.

RETScreen International, 2009. Renewable energy project analysis software. $\langle$ http://www.retscreen.net .

Rogers, M., 2001. Engineering Project Appraisal. Blackwell Science, Oxford, UK

Shum, K.L., Watanabe, C., 2008. Towards a local learning (innovation) model of solar photovoltaic deployment. Energy Policy 36 (2), 508-521.

Sustainable Energy Ireland, 2008a. Domestic fuel datasheet.〈http://www.sei.ie〉 (accessed on 17/10/2008).

Sustainable Energy Ireland, 2008b. Micro and small scale-generation pilot trial consultation. $\langle$ http://www.sei.ie/index.asp?locID=1708\&docID=-1 $\rangle$ (accessed on $20 / 11 / 2008$ ).

Twidell, J., Weir, T., 2006. Renewable Energy Resources. Taylor and Francis, New York.

van der Zwaan, B., Rabl, A., 2003. Prospects for PV: a learning curve analysis. Solar Energy 74 (1), 19-31.

\section{Glossary}

Annual degradation of PV yield (s): Percentage at which the maximum power degrades due to exposure to ultraviolet radiation (\%);

Balance of system (BOS): All PV system components other than the PV modules or cells;

BOS cost factor $\left(k_{\mathrm{bos}}\right)$ : BOS components cost relative to the cost of PV modules;

Discount rate $(D)$ : Interest rate used to discount future cash flows (\%);

Feed-in tariff (FIT): Policy mechanism designed to pay the producer of electricity at a specific rate usually higher than the purchase price;

Global radiation $\left(G_{m}\right)$ : Sum of beam (direct) and diffuse (indirect) solar radiation $\left(\mathrm{kWh} / \mathrm{m}^{2} / \mathrm{yr}\right)$;

Greenhouse gases (GHG): Gases in the atmosphere that absorb and emit radiation within the thermal infrared range:

Grid parity: When the cost of PV generated electricity equals that of grid supplied electricity;

Interest rate $(i)$ : Rate charged or paid for the use of money expressed as an annual percentage of the principal (\%);

Net present value (NPV): Sum of present value of costs associated with the PV module, initial BOS, replacement cost of BOS and variable cost $(€)$;

Peak power $\left(P_{\text {peak }}\right)$ : Maximum rated power under standard test conditions;

Performance ratio $(Q)$ : Indicator of how close a PV system approaches ideal performance during real operation and allows for comparison of PV systems independent of location, tilt angle, orientation and their nominal rated power capacity;

PV system life $(N)$ : Period during which a PV system produces energy (years);

Standard radiation $\left(I_{\text {stc }}\right)$ : Total solar radiation under standard test conditions for PV modules $\left(1 \mathrm{~kW} / \mathrm{m}^{2}\right)$;

Variable cost factor $\left(k_{v}\right)$ : Proportion of the initial investment used annually for system maintenance and insurance. 